\title{
Research on the Influence of Managerial Characteristics on Accounting Conservatism in Public Coal Companies during the period of COVID-19
}

\author{
Weimo Huang* \\ College of Management, Xi'an University of Science and Technology, Xi'an, 710054, China \\ *Corresponding Author.
}

\begin{abstract}
Objectives For a long time, scholars have been concerned about the impact of manager and team characteristics on corporate performance or corporate value, and the spread of COVID-19 forces us to consider the impact of manager characteristics on accounting conservatism. Methods This paper selects the financial data of 34 public coal companies from 2015 to 2019 as the research sample, establishes the measurement model of accounting conservatism based on Basu model to evaluate the accounting conservatism of public coal companies, and uses three regression models to study the impact of managers' age, education level and tenure on the accounting conservatism of companies. Results The results show that accounting conservatism is common in public coal companies, and the average value of $C$-score is greater than $O$ for five consecutive years. Conclusions Furthermore, the empirical results show that the regression coefficients of age and tenure of managers are 0.0224 and 0.0035 , respectively, which indicates that the age and tenure of managers have a positive impact on accounting conservatism. However, the level of education has no significant impact on the accounting conservatism of public coal companies, which depends on the particularity of production and management of public coal companies, and cannot completely deny the impact of education level on the conservatism.
\end{abstract}

Keywords: COVID-19, managers, characteristics, accounting conservatism

\section{Introduction}

The COVID-19 outbreak has greatly tested the ability of enterprise managers to deal with sudden major public events.As an important executive level, company managers have a very important role in the choice of their accounting policies following the company's economic operations and thus have a significant impact on accounting conservatism. For a long time, scholars have focused on the issue of the impact of managers and their team characteristics on company performance or company value, while research on the impact of company managers' characteristics on accounting conservatism needs to be deepened. Most of the public coal companies are state-owned companies, and it is special for them to appoint their managers, thus making the impact of their managerial characteristics on accounting conservatism different from that of non-state-owned companies. As a basic industry to ensure the normal life of the people, the operation and management of the coal industry after the epidemic has become the focus of the community.Therefore, public coal companies were selected as the research object to study the influence of managerial characteristics on accounting conservatism.

At present, scholars mainly study the impact of financial executives and chairpersons on accounting conservatism in terms of their academic level, tenure, age, gender, etc. LIU Yongli [1] found that managers' tenure and age are positively related to the accounting conservatism. LU Xin and LI Huimin [2] found that the average ages, tenures and education levels of managers of public companies penalized by China Securities Regulatory Commission (CSRC) are positively related to the occurrence of financial fraud. LU Ming [3] found that the academic level and competence of financial executives are positively related to the quality of accounting information of a company, and the higher the position and education level of the financial executives, the stronger they are in their competence, and the higher the quality of accounting information of the company. REN Rujuan [4] explored the relationship between the difference in tenures of chairpersons and financial executives and accounting

ISSN: 0010-8189

(C) CONVERTER 2021

www.converter-magazine.info 
conservatism of A-share public companies from 2009 to 2016 and came up with the results that the heterogeneity of tenures of chairpersons and financial executives is significantly and positively related to the level of accounting conservatism, and the financial executive serving earlier than the chairperson is more conducive to strengthening the accounting conservatism of a company.

According to the existing literature, most scholars used controller theory and contract theory as entry points to study the impact of managerial characteristics on the governance, value, and performance of companies, while relatively little literature involves the relationship between managerial characteristics and accounting conservatism. According to modern management science, managers are not "rational people" and cannot be rational at all times. In many cases, they make slightly different decisions based on their gender, age, education level and experience, which affects accounting conservatism. China's public coal companies are in a high-risk industry with high requirements and standards for safety management. The industry also has special characteristics in the appointment of the chairpersons, CFOs and general managers, which distinguish these companies from those in other industries. The age, tenure and education level of managers of public coal companies influence the choice of accounting policies of a company. Studying how their accounting conservatism is influenced by these three factors can play an important role in improving the quality of accounting information and optimizing the corporate governance structure of public coal companies.

\section{Theoretical Analysis and Research Hypothesis}

\subsection{The effect of managers' age on accounting conservatism}

Stevens, Beyer and Trice [5] found that managers' attitudes towards risk are strongly influenced by their age, the older the management, the higher the likelihood of avoiding risky decisions, and the younger managers have a greater tendency to adopt risky strategies. At the same time, managers' experience gets richer with age, their cognition varies with age, and the choice of strategic approach is influenced by their own cognitive level. Younger managers prefer to choose challenging matters and have a tendency to adopt expansive and riskier financial strategies, leading them to prefer aggressive accounting policies in the process of accounting policy selection. As they grow older, they gain more "experience" and are less likely to make impulsive decisions that have undesirable consequences. They are no longer concerned with short-term performance, but with long-term performance levels, and the stable development of the company in future years is their best choice. Therefore, they put long-term development strategy in their own planning, and they prefer a very robust accounting policy. Based on the above theoretical analysis, in this paper, the following hypothesis was made:

H1: Managers' age and accounting conservatism are positively correlated.

\subsection{The influence of managers' education level on accounting conservatism}

Education is not only a reflection of personal learning experience, but also an external expression of personal learning ability. Generally speaking, people with a higher education level are more proficient in professional skills and have higher level of external cognition, and they also have stronger ability in information processing. They can accurately use their own ability to think logically to make strategic decisions most suitable for the long-term development of the company. People with a higher level of education also have a longer-term perspective and see the long-term interests of the company as their starting point, so they plan to implement sound accounting policies that are beneficial to the future health of the company. However, if managers do not have high academic attainment, they tend to make decisions that are limited to their own vision and practical experience, and they may ignore the hidden economic risks when making strategic plans for the company. They are more willing to pursue short-term profits, and thus are more likely to choose aggressive accounting policies, reducing the level of accounting conservatism of the company. Based on the above theoretical analysis, in this paper, the following hypothesis was made:

ISSN: 0010-8189

(C) CONVERTER 2021

www.converter-magazine.info 
H2: Managers' education level and accounting conservatism are positively related.

\subsection{The effect of managers' tenure on accounting conservatism}

When a manager assumes a new management position, although his relevant ability can be judged based on his previous tenure, he has just been exposed to the new position. The market and external investors as well as the company internally know little about the manager and lack understanding, and can only rely on his recent business performance to evaluate his personal ability. In this way, to avoid being labeled as a "poor businessperson", which would have an impact on his own salary and tenure renewal, the manager has good reasons to manipulate the financial reporting data in order to present a better performance, thus reducing the conservatism of the company's accounting. However, managers' understanding of the company's operations deepens as their tenure lasts longer, when they have accumulated deeper industry experience and knowledge and a high reputation. To preserve their reputation in the industry, they will try to avoid "opportunistic" behavior and act more cautiously to improve the level of company's conservatism. Based on the above theoretical analysis, in this paper, authors made the following hypotheses:

H3: Managers' tenure and accounting conservatism are positively related.

\section{Research Design and Modeling}

\subsection{Sample selection and data sources}

In this paper, coal companies with A-shares listed in Shanghai Stock Exchange (SSE) and Shenzhen Stock Exchange (SZSE) from 2015-2019 were taken as the research object. China Stock Market \& Accounting Research Database (CSMAR) and relevant data disclosed in annual reports of public companies (excluding (special treatment) ST and public companies under *ST) were used, with 170 samples from 34 public coal companies finally obtained.

\subsection{Variable selection and modeling}

In this paper, the measurement model of accounting conservatism was first established to measure the evaluation results of accounting conservatism in different years and different public coal companies, and then three models were constructed to measure the influence of managerial characteristics on accounting conservatism.

\subsubsection{Indicator selection and measures of accounting conservatism level}

In the selection of indicators of accounting conservatism level, most scholars at home and abroad introduced some new variables to measure on the basis of Basu's model. Basu [6] first proposed the asymmetric timeliness (AT) to measure accounting conservatism. This is the most authoritative and widely circulated measuring approach. He argued that the level of accounting conservatism is reflected by the fact that accounting surplus reflects "unfavorable news" faster than "favorable news" and "positive" and "negative" stock returns measure positive "favorable news" and negative "unfavorable news", respectively. Basu suggested that the recognition of gains is more stringent than that of losses, which is a requirement of accounting conservatism, as losses often affect the upward and downward fluctuations of stock prices, so "differential timeliness" can be used to measure accounting conservatism through the time difference between the impact of gains and losses on stock prices, as shown in Equation (1):

$$
\operatorname{Eps}_{i, t} / P_{i, t-1}=\beta_{1}+\beta_{2} D r_{i, t}+\beta_{3} \operatorname{Re} t_{i, t} * D r_{i, t}+\varepsilon i, t
$$

However, there are shortcomings in the application of this method. Because the Basu model uses the annual return of individual stocks to measure the accounting conservatism, while the system of China's securities market is not well-developed, the change of operating results is in most cases not the main reason for the change of stock prices.

ISSN: 0010-8189 
Changes in government policies and macro-economy, human manipulation and other factors together cause changes in stock prices, so in most cases the operating result of a company cannot be expressed by the stock price. This indicator is mixed with many impurities, which becomes the disadvantage of the Basu model.

Therefore, based on the study of Khan and Watts [7], in this paper, an accounting conservatism measurement model based on the Basu model was established, with the company size (SIZE), the book-to-market ratio of the company's assets (M/B), the leverage (LEV), and the gross operating margin as control variables, and then the calculation of Equation (2) and Equation (3) was completed, in which Equation (2) used to confirm the timeliness of "favorable news" is replaced by G-score and Equation (3) is replaced by C-score. The procedure is as follows:

$$
\begin{aligned}
& G-\text { score }=\beta_{2}=\mu_{0}+\mu_{1} S I Z E+\mu_{2} M / B+\mu_{3} L E V \\
& C-\text { score }=\beta_{4}=\lambda_{0}+\lambda 1 S I Z E+\lambda_{2} M / B+\lambda_{3} L E V
\end{aligned}
$$

Substituting Equation (2) and Equation (3) into Equation (1) yields the measurement model of accounting conservatism:

$$
\begin{aligned}
& \text { Eps }_{i, t} / P_{i, t-1}=\beta_{1}+\left(\mu_{0}+\mu_{1} S I Z E+\mu_{2} M / B+\mu_{3} L E V\right) D r_{i, t}+\beta_{3} \operatorname{Re} t_{i, t} \\
& +\left(\lambda_{0}+\lambda_{1} S I Z E+\lambda_{2} M / B+\lambda_{3} L E V\right) \operatorname{Re} t_{i, t} * D r_{i, t}+\varepsilon_{i, t}
\end{aligned}
$$

Applying the regression analysis to the collected annual data of each indicator using Equation (4), the fuzzy values of the four coefficients $\lambda_{0}, \lambda_{1}, \lambda_{2}$, and $\lambda_{3}$ can be obtained, and then substituting these values one by one into Equation (3), the final value of the annual level of accounting conservatism C-score of each company for each year is obtained. The specific meaning and calculation method of variables are shown in Table 1.

Table 1 Variables

\begin{tabular}{|c|c|}
\hline Variable symbol & Meaning and calculation method \\
\hline Epsi,t & Represents the earnings per share of company $\mathrm{i}$ in year $\mathrm{t}$ \\
\hline Pi,t-1 & Represents the opening price of company i's stock at the beginning of year $\mathrm{t}$ \\
\hline Reti,t & Represents the stock return of company $\mathrm{i}$ in year $\mathrm{t}$ \\
\hline Dri,t & Dummy variable is set to 1 if Reti, $\mathrm{t}<0$, otherwise it is 0 \\
\hline SIZE & Natural logarithm of total assets \\
\hline M/B & Ending ratio of total assets to market value \\
\hline LEV & Ratio of total liabilities to total assets \\
\hline
\end{tabular}

3.2.2 Modeling to measure the influence of manager characteristics on accounting conservatism

As mentioned above, the results of accounting conservatism index C-scores of different companies in each year are obtained by using Equation (4). Then, the results are set as the interpreted variable C-score to create an empirical analysis model reflecting the influence of managerial characteristics on accounting conservatism, with Age, education level (Degree) and Tenure measuring managerial characteristics as explanatory variables, so as to test three hypotheses of the influence of managers' age, education level and tenure on accounting conservatism, the relevant independent variable and control variable indicators are shown in Table 2.

The actual ages of chairpersons, general managers and CFOs are added and the average value is set as Age, which is used to represent the age characteristics of managers. That is, with the increase of the Age, managers' cognitive level and experience are enhanced. The related indicators of Degree are set as follows: "1" means technical

ISSN: 0010-8189 
secondary school or below, "2" means junior college, "3" means undergraduate, "4" means master's degree, and "5" means doctor's degree. That is to say, the academic level of managers is higher with the increase of academic indicator value. The variable "Degree" is obtained by adding up the educational indicators of the chairpersons, general managers and CFOs, which is used to measure the educational level of chairpersons, general managers and CFOs. The average value obtained by adding the tenures of chairpersons, general managers and CFOs is set as Tenure, expressed in month, and the Tenure is used to represent the tenure characteristics of managers.

On this basis, the model is established as follows:

$$
\begin{array}{ll}
C-\text { score }=\delta_{1} \text { Age }+\delta_{2} S I Z E+\delta_{3} M / B+\delta_{4} L E V+\delta_{5} M L L+\gamma_{1} & \text { Model } 1 \\
C-\text { score }=\chi_{1} \text { Degree }+\chi_{2} S I Z E+\chi_{3} M / B+\chi_{4} L E V+\chi_{5} M L L+\gamma_{2} & \text { Model } 2 \\
C-\text { score }=\rho_{1} \text { Tenure }+\rho_{2} S I Z E+\rho_{3} M / B+\rho_{4} L E V+\rho_{5} M L L+\gamma_{3} & \text { Model } 3
\end{array}
$$

Table 2 Variables

\begin{tabular}{|c|c|c|}
\hline Variable type & Variable symbol & Calculation method \\
\hline \multirow{4}{*}{$\begin{array}{c}\text { Independent } \\
\text { variable }\end{array}$} & Age & $\begin{array}{c}\text { Average age of chairpersons, general managers and } \\
\text { chief financial officers }\end{array}$ \\
\cline { 2 - 3 } & Degree & $\begin{array}{c}\text { Average education level of chairpersons, general } \\
\text { managers and chief financial officers }\end{array}$ \\
\cline { 2 - 3 } & Tenure & $\begin{array}{c}\text { Average tenure of chairpersons, general managers } \\
\text { and chief financial officers }\end{array}$ \\
\hline \multirow{3}{*}{\begin{tabular}{c} 
Control variable \\
\cline { 2 - 3 }
\end{tabular}} & SIZE & Natural logarithm of total assets \\
\cline { 2 - 3 } & M/B & Total assets/market value at the end of a period \\
\cline { 2 - 3 } & MLL & Total liabilities/total assets \\
\hline
\end{tabular}

When choosing the SIZE of a company as a control variable, it is mainly considered that the size of a company is usually linked with its political cost. If the company goes larger, it may produce a higher political cost. A high political cost is usually caused by the attention of administrative authorities at home, investment partners of the company and mass media. Regulators are more inclined to turn their attention to companies with ever-expanding scale, which will get more and more attention from regulators as the scale of a company grows. It is an inevitable choice for such companies to keep a low profile and adopt sound accounting policies, which can also achieve the purpose of reducing political cost. At the same time, in this paper, the book-to-market ratio (M/B) and leverage (LEV) are taken as two control variables. Because creditors' attention to a company increases with the increase of debt, if the public supervision is strengthened, the possibility of managers' opportunism will be reduced, which will eventually affect the company's sound accounting policy. The gross operating margin is also taken as the control variable. Generally, the higher the gross operating margin is, the stronger the accounting conservatism of a company will be.

\section{Empirical Analysis Results and Analysis}

\subsection{Analysis on descriptive statistics}

4.1.1 Analysis on descriptive statistics of accounting conservatism According to Equation (4), the indicator value of accounting conservatism (C-score) is measured. From Table 3, it can be seen that the average value of $\mathrm{C}$-score is greater than 0 for five consecutive years, which indicates that all the selected public coal companies have accounting conservatism, and the accounting conservatism results of different companies vary from year to year, with little difference in the maximum value from year to year, and the average value shows an increasing trend year by year. The standard deviation of C-score in each year is about 0.37 ,

ISSN: 0010-8189 
which shows that the deviation degree of conservatism in each company is similar every year. Therefore, accounting conservatism is widespread in public coal companies.

Table 3 Descriptive statistics of accounting conservatism

\begin{tabular}{|c|c|c|c|c|c|}
\hline Variable & $\mathrm{N}$ & Min. & Max. & Average & Standard deviation \\
\hline C-score(2015) & 34 & 0.921 & 2.829 & 1.873 & 0.377 \\
\hline C-score(2016) & 34 & 1.077 & 2.867 & 1.868 & 0.383 \\
\hline C-score(2017) & 34 & 0.893 & 2.694 & 1.947 & 0.378 \\
\hline C-score(2018) & 34 & 1.028 & 2.906 & 2.120 & 0.373 \\
\hline C-score(2019) & 34 & 0.976 & 3.034 & 2.103 & 0.393 \\
\hline
\end{tabular}

4.1.2 Analysis on descriptive statistics of managers' age, educational level and tenure

According to Table 4, the average Age of managers in public coal companies is about 52 years old, indicating that the management of such companies is generally around 50 years old, and the minimum age is about 46 years old, indicating that the managers of such companies in China are generally old; the average Degree of managers in public coal companies is greater than 3, indicating that most of the educational levels of managers in such companies are undergraduate and master's degree, and the minimum value is 2 , indicating that a small number of managers are graduated from junior colleges; the average Tenure of managers in public coal companies is about 41.2 months, indicating that most managers in such companies have been in office for more than three years, and the minimum value is 5 , indicating that some managers leave earlier and have shorter tenure.

Table 4 Descriptive statistics of managers' age, educational level and tenure

\begin{tabular}{|c|c|c|c|c|c|}
\hline Variable & $\mathrm{N}$ & Min. & Max. & Average & Standard deviation \\
\hline Age & 170 & 45.667 & 57.667 & 51.751 & 2.675 \\
\hline Degree & 170 & 2 & 4.667 & 3.652 & 0.537 \\
\hline Tenure & 170 & 5 & 117.667 & 41.153 & 22.344 \\
\hline
\end{tabular}

4.1.3 Analysis on descriptive statistics of company size, book-to-market ratio and leverage

According to the analysis results of descriptive statistics in Table 5, the SIZE of public coal companies ranges from 21.194 to 27.099 , with a standard deviation of 1.127 , which indicates that there is a big difference in the size of public coal companies. The average value of book-to-market ratio (M/B) is 0.942 , and its standard deviation is 0.178 , which indicates that the book value of net assets of most public coal companies in China is a little smaller than their market value. The average value of LEV is 0.552 , which indicates that the level of LEV of public coal companies in China is $55.2 \%$. At the same time, it can be concluded that the average gross operating margin is 0.254 , which indicates that the gross margin of most public coal companies is positive and the ability to obtain profits is strong.

Table 5 Descriptive statistics of company size, book-to-market ratio and leverage

\begin{tabular}{|c|c|c|c|c|c|}
\hline Variable & $\mathrm{N}$ & Min. & Max. & Average & Standard deviation \\
\hline SIZE & 170 & 21.194 & 27.099 & 23.978 & 1.127 \\
\hline M/B & 170 & 0.405 & 1.361 & 0.942 & 0.178 \\
\hline LEV & 170 & 0.213 & 0.941 & 0.552 & 0.158 \\
\hline MLL & 170 & -0.409 & 0.554 & 0.254 & 0.147 \\
\hline
\end{tabular}

\subsection{Hausman test}

Before regression analysis, the Hausman test was used to test the relevant hypothesis of the collected sample data, and test whether the fixed or random effect model should be established, the results of Hausman test are shown in Table 6 .

ISSN: 0010-8189

(C) CONVERTER 2021

www.converter-magazine.info 
Table 6 Hausman test results of three models

\begin{tabular}{|c|c|c|c|c|}
\hline Test item & Chi-Sq. statistics & $\begin{array}{c}\text { Chi-Sq. degree of } \\
\text { freedom }\end{array}$ & Significance level & Test result \\
\hline Model 1 & 11.082967 & 5 & 0.0498 & Fixed effects model \\
\hline Model 2 & 4.711093 & 5 & 0.0521 & Fixed effects model \\
\hline Model 3 & 59.513032 & 5 & 0.0001 & Fixed effects model \\
\hline
\end{tabular}

Through the Hausman test of the above models, it can be seen that the $\mathrm{P}$ values of the three models are all less than 0.1 , and the $\mathrm{P}$ values of Model 1 and Model 3 are less than 0.05, which indicates that the original hypothesis is rejected at $90 \%$ confidence level, so fixed effects shall be taken for the three models.

\subsection{Results of regression analysis}

By using Stata software, regression analysis is carried out with the measured results of accounting conservatism level of companies by using three indicators of managers, namely, age, educational level and tenure, and the results are shown in Table 7:

Table 7 Regression results of three models

\begin{tabular}{|c|c|c|c|}
\hline \multirow{2}{*}{ Variable } & \multicolumn{3}{|c|}{ C-score } \\
\hline & Model 1 & Model 2 & Model 3 \\
\hline Age & $\begin{array}{c}0.022357 * * * \\
(2.341576)\end{array}$ & l & I \\
\hline Degree & I & $\begin{array}{l}9.79 \mathrm{e}-09 \\
(0.35)\end{array}$ & I \\
\hline Tenure & / & / & $\begin{array}{c}0.003549 * * * \\
(4.385742)\end{array}$ \\
\hline SIZE & $\begin{array}{c}0.091738 * * * \\
(7.11 \mathrm{E}+08)\end{array}$ & $\begin{array}{c}0.0917375 * * * \\
\quad(4.0 \mathrm{e}+06)\end{array}$ & $\begin{array}{c}0.015658 * * * \\
(1.612588)\end{array}$ \\
\hline $\mathrm{M} / \mathrm{B}$ & $\begin{array}{c}0.799529 * * * \\
(2.28 \mathrm{E}+09)\end{array}$ & $\begin{array}{c}0.7995295^{* * * *} \\
(1.2 \mathrm{e}+07)\end{array}$ & $\begin{array}{c}0.019641 * * * \\
(0.725235)\end{array}$ \\
\hline LEV & $\begin{array}{l}-2.207735 * * * \\
(-3.63 E+09)\end{array}$ & $\begin{array}{c}-2.207735 * * * \\
(-2.0 \mathrm{e}+07)\end{array}$ & $\begin{array}{c}-0.059348 * * * \\
(-1.313039)\end{array}$ \\
\hline MLL & $\begin{array}{c}6.62 \mathrm{E}-10 * * * \\
(1.757596)\end{array}$ & $\begin{array}{c}-2.69 \mathrm{e}-09 \\
(-0.04)\end{array}$ & $\begin{array}{c}0.078728 * * * \\
(2.709058)\end{array}$ \\
\hline C-score & $\begin{array}{l}-3.29 \mathrm{E}-11 * \\
(-1.846092)\end{array}$ & $\begin{array}{c}0.2507197 * * * \\
(5.1 \mathrm{e}+05)\end{array}$ & $\begin{array}{c}1.401435 * * * \\
(6.581134)\end{array}$ \\
\hline R-Squared & 1.000000 & 1.000000 & 0.995200 \\
\hline F-statistic & $3.86 \mathrm{E}+18$ & $1.88 \mathrm{e}+14$ & 679.1653 \\
\hline $\begin{array}{l}\text { Test results of } \\
\text { hypotheses }\end{array}$ & Hypothesis 1 passed the test & $\begin{array}{c}\text { Hypothesis } 2 \text { failed the } \\
\text { test }\end{array}$ & Hypothesis 3 passed the test \\
\hline
\end{tabular}

Note: $* * *, * *, *$ mean significant at $1 \%, 5 \%$ and $10 \%$ levels, respectively.

Table 7 is the regression results of the three models, among which, the age and tenure of managers in Model 1 and Model 3 are significant at $1 \%$, which shows that the age and tenure of managers in public coal companies have a significant impact on accounting conservatism. The regression coefficients of managers' age and tenure are 0.022357 and 0.003549 , respectively, indicating that managers' age and tenure have a positive impact on accounting conservatism. However, in Model 2, the Degree of managers is not significant at $1 \%$, which shows that the educational level of managers has no significant influence on accounting conservatism.

ISSN: 0010-8189

(C) CONVERTER 2021

www.converter-magazine.info 


\subsection{Discussion of empirical results}

Hypothesis 1 holds that there is a positive correlation between the age of corporate managers and accounting conservatism that the older the coal company management, the higher the conservatism of the company. This is consistent with the characteristics of coal production and management. Coal companies are in a high-risk industry, and they have very high requirements for safe production. At the same time, COVID-19's global spread has increased the uncertainty of coal market risks, managers of coal companies often need to accumulate rich experience in production and market. When managers are older, their own accumulated experience in production safety and management is deeper, and the risks in the market environment are easily captured fully. Therefore, they are more inclined to keep the company's long-term stable survival and development as their management goal, and the choice of accounting policies will naturally be significantly affected by this goal, that is, the managers of such public coal companies are more willing to choose more stable accounting policies. However, according to the regression results of models, although there is a significant positive correlation between managers' age and accounting conservatism, its influence intensity is weak from the regression coefficient, which indicates that the age structure of managers in public coal companies may still be unreasonable. It may be rooted that companies' management training systems are not sound enough, and the comprehensive quality of young managers who can fully adapt to market changes cannot meet the requirements of stable development of public coal companies. Therefore, public coal companies should pay more attention to the rationalization of the age structure of managers in the development process of post-epidemic era.

The hypothesis of positive correlation between educational level and accounting conservatism in Hypothesis 2 is not valid. The research results of this paper show that educational level has no significant influence on accounting conservatism in public coal companies, which is contrary to expectations. From a theoretical point of view, a high degree of education represents a high level of management ability to a certain extent. Managers with a higher educational level will take the long-term interests of the company as the starting point, formulate their own management position development goals according to the long-term development goals of the company, and strive to develop in step with or ahead of the company. Therefore, they will be more inclined to choose robust accounting policies that are more beneficial to the long-term development of the company. However, public coal companies have high risks in safe operation, and have higher requirements for managers' risk management ability and experience. When selecting managers, the requirements for academic qualifications are weaker than those for experience. At the same time, these managers who have more practices and experience have obtained higher academic qualifications through post-academic education. However, this kind of academic education is often more inclined to obtain academic certificates, so the impact of academic qualifications on accounting conservatism is not obvious. According to the regression results of Model 2 established in this paper, although it can be considered statistically that the educational level has no significant influence on the accounting conservatism of a company, it is inconsistent with the research results of relevant literature at home and abroad, which is determined by the particularity of production and management of public coal companies, and the influence of educational level on the conservatism cannot be completely denied. Moreover, the novel coronavirus pneumonia epidemic will be a protracted battle, and with the global economic downturn continuing, the reserve of high-level talent is crucial.

Hypothesis 3 holds that the length of tenure is positively correlated with accounting conservatism. Regression data show that the managerial characteristics in public coal companies have a significant impact on accounting conservatism, and from the current data, the longer the tenure of managers, the higher the conservatism level, and there is a significant positive correlation between them. This situation is consistent with expectations, which further shows that the managers of public coal companies who have a long tenure have finally become the managers of such companies through hierarchical selection in the course of the company's operation, and they often experience longer working years than the managers of other industries. Therefore, they will pay more attention to the maintenance of their "honor", and when they take office in higher positions, they will not easily choose radical accounting policies, but will choose robust accounting policies that are beneficial to the future development of the company. In this "big test" of epidemic situation, only by changing management thinking,

ISSN: 0010-8189

(C) CONVERTER 2021

www.converter-magazine.info 
adapting to the new layout and new trend, and grasping the opportunities in crisis, can enterprises survive and develop. It is obvious that the long-term managers can implement the company's long-term development strategy more steadily, have a sustainable control over the company's future development direction, fully realize the sustainable development strategy of the coal company, encourage the coal company to improve its internal management efficiency, fully consider the environmental and ecological pressures in the company's operations, and achieve a win-win situation for the company's operating performance and ecological environment benefits.

\section{Suggestive Countermeasures}

Managers' characteristics directly affect the accounting policy choice of coal listed companies, and then have an impact on the accounting conservatism level of companies. In order to improve the beneficial influence of managerial characteristics on accounting conservatism, the following suggestive countermeasures are proposed.

\subsection{To optimize the age structure of managers of public coal companies}

When forming the management team of a company, we should pay attention to keeping the age of managers at a scientific and reasonable level and matching suitable managers [8]. From the previous analysis, it can be seen that younger managers are more responsive to the market and can quickly choose accounting policies suitable for the company according to environmental changes, while older managers are well-informed for many years and have accumulated rich experience and practices, so they have a long-term vision, and they are more willing to implement accounting policies with a high degree of stability in the company. Whether the policy is radical or too conservative, it will have an adverse impact on the future of the company. Setting a scientific age structure for managers will encourage companies to give up opportunism, flexibly deal with the emergencies that may be caused by the late epidemic, make plans in advance to avoid risks or seize opportunities, thus improving companies' viability.

\subsection{To establish and improve the tenure continuity system of company managers}

The selected managers need to survive in the company for a long time and stabilize the company's development, which requires the establishment of a sound tenure continuity system for managers [9]. From the above empirical conclusions, it can be concluded that the longer a manager's tenure is, the better his continuity will be, and s/he will pay more attention to "honor" and reputation in the industry, avoiding too radical accounting policies. Managers with a short tenure are often evaluated by the outside world for their short-term performance, and may manipulate accounting information disclosure in order to achieve better performance. However, managers with a long tenure have accumulated rich knowledge and experience in the industry and have a certain reputation. When choosing accounting policies, they will skip opportunism and give priority to accounting policies with a high degree of stability, thereby preserving their position and reputation in the industry. Therefore, companies should improve the policies related to the tenure continuity of managers, and encourage managers to obtain effective tenure, thereby improving the benefits brought by the company's accounting conservatism.

\subsection{To select managers with both academic qualifications and experience balanced}

The higher the educational level, the stronger the comprehensive management and analysis ability [10]. When managers make relevant management decisions, they not only consider the problems more comprehensively, but also fully weigh the economic consequences of different accounting policy choices, especially the impact on the accounting conservatism level; at the same time, managers with much more experiences can make full use of their theoretical knowledge and rich practical management experience, analyze the advantages and disadvantages faced by the company in combination with the internal and external environments, competitive pressure and various risks faced by the company, and better cooperate with other managers to formulate strategic policies of the company. Therefore, public coal companies should provide more platforms for managers to continue learning, and encourage

ISSN: 0010-8189 
managers to form a good learning atmosphere by fully combining their own education and experience, so as to stimulate the vitality of the company, which is particularly important in the post-epidemic era.

\section{Acknowledgment}

This work was supported by the General Program Funded by National Social Science Foundation of China (Grant No. 20BJY076).

\section{References}

[1] Z.G. Zhang, Y.L. Liu, D.J. Tan, "Background characteristics of managers and accounting conservatism-empirical evidence from Chinese public companies,” Accounting Research, no. 7, pp. 11-18, 2011.

[2] X. Lu, "Research on the background characteristics of executives and financial fraud-based on the empirical data of Chinese public companies," Journal of Audit \& Economics, no. 5, pp. 58-67, 2015.

[3] M. Lu, "CFOs' professional ability, power intensity and accounting information quality," Hainan University, 2016.

[4] R.J. Ren, "A substantial study on the influence of CEO tenure on accounting conservatism," Communication of Finance and Accounting, no. 21, pp. 25-28, 2016.

[5] J.M. Stevens, J.M. Beyer, "Assessing personal, role, and organizational predictors of managerial commitment," Academy of Management Journal, vol. 21, no. 4, pp. 380-396, 1978.

[6] S. Basu, "The Conservatism Principle and the Asymmetric Timeliness of Earnings," Journal of Accounting and Economics, vol. 24, no. 1, pp. 3- 37, 1997.

[7] M. Khan, R.L. Watts "Estimation and empirical properties of a firm-year measure of accounting conservatism," Journal of Accounting and Economics, vol. 48, no. 2, pp. 132-150, 2009.

[8] Z.J. Lin, Z.M. Tian, “Accounting conservatism and IPO underpricing: China evidence," Journal of International Accounting, Auditing and Taxation, vol. 21, no. 2, pp. 127-144, 2012.

[9] W.H. Kai; S. Klasa; P.E. Yeung. "Corporate suppliers and customers and accounting conservatism," vol. 53, no. 1, pp. 122-135, 2012.

[10] P. Demetrio, "Economic insecurity, conservatism, and the crisis of environmentalism: 30 years of evidence," Socio-Economic Planning Sciences, vol. 73, no. 2, pp. 100925, 2021.

ISSN: 0010-8189 